\title{
Trichomoniasis in Nigeria: a review.
}

\section{Omorodion Oriri Asemota*}

Industrial Safety and Environmental Technology Department, Petroleum Training Institute, Effurun, Nigeria

\begin{abstract}
Sexually Transmitted Parasitic Diseases (STPDs) are infectious diseases that are transmitted via unprotected sex which could potentially predispose men and women to different reproductive health issues. The data presented in this report shows that, trichomoniasis caused by Trichomonas vaginalis (TV) remain the only reported sexually-transmitted parasitic disease in Nigeria. Also, of the 36 states in the country, only 26 states including the Federal Capital Territory (FCT), Abuja have partly evaluated the prevalence of the disease. Furthermore, the prevalence data on the burden of TV infections in Nigeria in form of Years Lived with Disability (YLD), the distribution of the infection in the six geopolitical zones and the prevalence over the years are presented. Notably, YLD for TV infection was highest in the South-South; while the factors possibly impacting on the burden of TV in Nigeria are highlighted.
\end{abstract}

Keywords: Sexually transmitted parasitic diseases (STPDs), Trichomoniasis, Nigeria.

Accepted on April 18, 2018

\section{Introduction}

Sexually Transmitted Diseases (STDs) being transmitted by sex through different routes are amongst the commonest communicable diseases globally with more than 1 million new infection daily [1]. The burden of STDs largely occurs in developing countries [2]; with the most vulnerable, disproportionately affected by other health and socialeconomic issues. In developing countries, STDs are among the leading causes of Disability-Adjusted Life Years (DALYs) lost for women of reproductive age [3].

Parasitic STDs include trichomoniasis, amoebiosis and giardiasis $[4,5]$. Infection with Sexually Transmitted Parasitic Diseases (STPDs) has resulted in debilitation or anatomic deformities that make sex impossible as a result of direct damage to the male and female reproductive organs including impairing fertility via the inhibition of gamete production [6].

Trichomonas vaginalis is the most common STPDs in Nigeria; and studies on STPDs remain relatively scanty [7-10]. In addition, knowledge about $T$. vaginalis and trichomoniasis is hugely lacking; and this identified gap may have impacted on the burden of infection.
This review article thus present prevalence data for Nigeria by states; and highlight the gaps in information regarding various aspects of the disease. Further, the implication of the relatively lack of awareness about $T$. vaginalis infection were noted and discussed.

\section{Prevalence and Distribution of STPDs}

In Nigeria, amongst the vast array of endemic parasitic diseases, only trichomoniasis is sexually transmitted. There are other parasites that could be transmitted via oral-anal and oralgenital routes and as such can elicit other forms of sexually transmitted diseases. Of the 36 states and Abuja, T. vaginalis studies could only be accessed for twenty-six (26) states (Table 1). These studies spanned through the different geo-political zones (South-East, South-South, South-West, North-West, North-East and North-North) of the country. In spite of this, there is still limited/lack of literature on the prevalence of $T$. vaginalis infection in some other states. From available data, the prevalence across the country ranged between $0-51.8 \%$. Majority of these studies were carried out on pregnant women in the different geo-political zones, and samples were mostly vaginal swab (Table 1).

Table 1. Prevalence of trichomoniasis across zones and states.

\begin{tabular}{llllll}
\hline Zone & State & Participants & Number tested & Prevalence (\%) & Sample (s) used \\
\hline South-East & Ebonyi & HIVIAIDS patients & 970 & 36.6 & Urine \\
\cline { 2 - 6 } & Anambra/Enugu & Male adolescents & 361 & 25.2 & $\begin{array}{l}\text { Urine, urethral smears, [12] } \\
\text { semen }\end{array}$
\end{tabular}




\begin{tabular}{|c|c|c|c|c|c|c|}
\hline & Ebonyi & HIV-seropositive women & 250 & 24.4 & Urine, HVS & [13] \\
\hline & Abia & Women & 600 & 18.67 & Urine, HVS & {$[7]$} \\
\hline & Anambra & $\begin{array}{l}\text { Women between } 20 \\
\text { years and above }\end{array}$ & 200 & 17.5 & HVS & [14] \\
\hline & Abia & Pregnant women & 200 & 13 & HVS & [15] \\
\hline & Anambra & Rural women & 100 & 15 & HVS & {$[16]$} \\
\hline & Anambra & Women & 1440 & 21.53 & Urine, HVS & [17] \\
\hline & Anambra & Females & 100 & 2.3 & Blood, HVS & [18] \\
\hline & Ebonyi & Pregnant women & 688 & 12.9 & Vaginal swab & [19] \\
\hline & Ebonyi & Antenatal patients & 200 & 27.5 & HVS & [20] \\
\hline & Ebonyi & $\begin{array}{l}\text { Single and married } \\
\text { pregnant women }\end{array}$ & 1025 & 12.3 & Vaginal swab & [21] \\
\hline & Imo & $\begin{array}{l}\text { Female/adult } \\
\text { patients }\end{array}$ & 1241 & 10.2 & HVS & [22] \\
\hline & Imo & Males & 178 & 3.4 & US & [22] \\
\hline & Imo & Males and females & 5883 & 1.3 & US & [22] \\
\hline \multirow[t]{12}{*}{ South-South } & Edo & Pregnant women & 150 & 0 & Urine & [23] \\
\hline & Cross-River & Pregnant women & 562 & 5.2 & HVS & [24] \\
\hline & Bayelsa & $\begin{array}{l}\text { Females patients with } \\
\text { vaginal complaints }\end{array}$ & 1240 & 6.5 & HVS, ECS & [25] \\
\hline & Edo & $\begin{array}{l}\text { Pregnant/non-pregnant } \\
\text { women }\end{array}$ & 300 & 2.8 & HVS & [26] \\
\hline & Akwa-lbom & Pregnant women & 260 & 17.7 & HVS & [10] \\
\hline & Rivers & $\begin{array}{l}\text { Women attending } \\
\text { antenatal, gynaecology, } \\
\text { family planning and } \\
\text { sexually transmitted } \\
\text { disease clinics }\end{array}$ & 220 & 4.5 & HVS & [27] \\
\hline & Rivers & $\begin{array}{l}\text { Women from urban and } \\
\text { sub-urban areas }\end{array}$ & 1431 & 0.63 & HVS & [28] \\
\hline & Edo & $\begin{array}{l}\text { Adolescent girls in } \\
\text { secondary schools }\end{array}$ & 272 & 9.2 & HVS & [29] \\
\hline & Akwa-lbom & HIV-seropositive people & 150 & 16.2 & HVS, urine & [30] \\
\hline & Akwa-lbom & Pregnant women & 560 & 44.5 & HVS, ECS & [31] \\
\hline & Delta & Women at Effurun & 100 & 6 & HVS & [32] \\
\hline & Delta & $\begin{array}{l}\text { Secondary school girls, } \\
\text { teachers, } \\
\text { undergraduates and } \\
\text { petty traders }\end{array}$ & 240 & 22.5 & Urine, HVS & [33] \\
\hline \multirow[t]{6}{*}{ South-West } & Ogun & $\begin{array}{l}\text { HIV-infected and non- } \\
\text { infected women }\end{array}$ & 100 & 5 & Urine, HVS & [34] \\
\hline & Osun & Female patients & 310 & 8.1 & HVS, ECS, US & [35] \\
\hline & Oyo & Pregnant women & 100 & 6 & HVS & [36] \\
\hline & Osun & Pregnant women & 100 & 2 & HVS & [37] \\
\hline & Ogun & Pregnant women & 300 & 10.3 & HVS & [38] \\
\hline & Ogun & Pregnant women & 200 & 20 & HVS, Urine & [39] \\
\hline
\end{tabular}


Trichomoniasis in Nigeria: a review

\begin{tabular}{|c|c|c|c|c|c|c|}
\hline & Lagos & Pregnant women & 198 & 18.7 & HVS & [40] \\
\hline & Ibadan & ARFH attendees & 200 & 1.5 & Blood, HVS, ECS & [41] \\
\hline & Oуо & $\begin{array}{l}\text { Pregnany ante-natal } \\
\text { patients }\end{array}$ & 150 & 25.3 & HVS & [42] \\
\hline & Lagos & Women (outpatients) & 544 & 3.3 & HVS & [43] \\
\hline & Ondo & $\begin{array}{l}\text { Seropositive and sero } \\
\text { negative } \\
\text { women }\end{array}$ & 240 & 50 and 22 & HVS & [44] \\
\hline & Ondo & $\begin{array}{l}\text { Seropositive and sero } \\
\text { negative males and } \\
\text { females }\end{array}$ & 100 & 0 and 6 & Urine and HVS & [45] \\
\hline & Ibadan & $\begin{array}{l}\text { Sexual partners of } \\
\text { women with confirmed } \\
\text { diagnosis of TV }\end{array}$ & 44 & 45.5 & Urethral swap & [46] \\
\hline & Ogun & $\begin{array}{l}\text { Female students } \\
\text { Babkock University }\end{array}$ & 200 & 12.5 & HVS & [47] \\
\hline & Lagos & $\begin{array}{l}\text { Patients with virginal } \\
\text { discharge }\end{array}$ & 200 & 74.5 & HVS & [48] \\
\hline & Ogun & $\begin{array}{l}\text { University male female } \\
\text { students in redemption } \\
\text { camp }\end{array}$ & 60 & 1.67 and 3.3 & urine & [43] \\
\hline North-West & Kaduna & Pregnant women & 120 & 19.2 & HVS, Blood & [49] \\
\hline & Kebbi & Female patients & 220 & 4.1 & Urine, HVS & [50] \\
\hline & Jigawa & Female patients & 150 & 1.3 & HVS & [51] \\
\hline & Kano & $\begin{array}{l}\text { Females with abnormal } \\
\text { vaginal discharges }\end{array}$ & 2000 & 1.5 & ECS, HVS & [52] \\
\hline & Kaduna & $\begin{array}{l}\text { Females living in } \\
\text { Palladan }\end{array}$ & 150 & 13.67 & HVS & [53] \\
\hline & Kaduna & $\begin{array}{l}\text { HIV-seropositive } \\
\text { antenatal clients }\end{array}$ & 102 & 5.9 & HVS & [54] \\
\hline North-East & Borno & Female IDPs & 200 & 20.5 & HVS & {$[8]$} \\
\hline & Borno & Pregnant women & 919 & 10.99 & HVS & [55] \\
\hline & Adamawa & $\begin{array}{l}\text { Health males, females, } \\
\text { antenatal women, and } \\
\text { sick males and females } \\
\text { without any history of } \\
\text { Trichomoniasis }\end{array}$ & 1520 & 2.6 & Blood and genital swab & [56] \\
\hline North-Central & Plateau & HIV-1 infected women & 168 & 51.8 & HVS & [57] \\
\hline & Nasarawa & Pregnant women & 960 & 7.5 & Urine, HVS & [58] \\
\hline & Nasarawa & Female patients & 200 & 8.5 & Vaginal discharge & [59] \\
\hline & Kwara & Pregnant women & 250 & 20 & HVS, Urine & [60] \\
\hline & Plateau & Female & 150 & 4 & HVS & [61] \\
\hline & FCT, Abuja & Primary school pupils & 402 & 3.73 & Urine, stool & [62] \\
\hline & Kwara & Pregnant women & 230 & 4.7 & & [63] \\
\hline & Kwara & $\begin{array}{l}\text { HIV-seropositive } \\
\text { antenatal clients }\end{array}$ & 160 & 5.6 & ECS, HVS & [64] \\
\hline & Benue & Females patients & 200 & 10.5 & HVS, Urine & [65] \\
\hline & Benue & $\begin{array}{l}\text { Male and female } \\
\text { patients }\end{array}$ & 400 & 12 & Urine & [66] \\
\hline
\end{tabular}




\begin{tabular}{|c|c|c|c|c|c|}
\hline Nasarawa & Female patients & 100 & 12 & HVS & [67] \\
\hline Nasarawa & $\begin{array}{l}\text { Male and female } \\
\text { patients }\end{array}$ & 1050 & 15.71 & Urine, HVS & [68] \\
\hline FCT, Abuja & $\begin{array}{l}\text { Male and female } \\
\text { patients }\end{array}$ & 286 & 15 & $\begin{array}{l}\text { Blood, ECS, HVS, } \\
\text { Urine, Urethal swabs, } \\
\text { Urethal discharge }\end{array}$ & [69] \\
\hline Nasarawa & $\begin{array}{l}\text { Female students of } \\
\text { Bingham University }\end{array}$ & 200 & 4.5 & Low vaginal swabs & {$[70]$} \\
\hline Plateau & $\begin{array}{l}\text { HIV positive and } \\
\text { negative patients }\end{array}$ & 700 & 17 & HVS & [71] \\
\hline
\end{tabular}

HVS: High Vaginal Swab; ECS: Endocervical Swap; US: Urethral Sample; HIV: Human Immunodeficiency Virus; AIDS: Acquired Immune Deficiency Syndrome.

The prevalence of $T$. vaginalis infection is relatively higher in sexually active women [9]. In males, T. vaginalis infection is generally trivial or asymptomatic. Asymptomatic carriers can serve as vectors for the disease, making it important to treat male partners. The parasite resides in the female's lower genital tract and the male urethra and prostate.

Reports from Nigeria suggest that, trichomoniasis could be higher in urban areas than in the rural communities [72,73]. For example, in a study carried out by [74], a higher prevalence of $T$. vaginalis was documented for subjects that resided in urban areas $(57.70 \%)$ than those that lived in rural communities (39.16\%). Also, prevalence was highest amongst the sexually active group of age 11-45 years old [7].

Amongst pregnant women, $T$. vaginalis is generally high $[9,39]$. In Zaria, pregnant women between ages 16 to 25 were reported to be $T$. vaginalis positive with prevalence of $53.57 \%$ [43]. In Lagos, South-West, Nigeria, T. vaginalis prevalence of $1.8 \%$ was recorded for pregnant women between 21 to 30 years old. Similarly, in Abeokuta, South-West Nigeria, pregnant women between the age 20 and 30 had prevalence of 21.3\%. Meanwhile in Anambra, South-East Nigeria, nonpregnant women had higher rate of infection (17.8\%) than pregnant ones (16.7\%) [14]. Furthermore, a study in Maiduguri showed a high rate of $20.8 \%$ infection among non-pregnant women [8].

In relation to marital status, a prevalence of $2.9 \%$ was recorded among Lagos married women compared to $0.4 \%$ prevalence in unmarried women [43]. Amadi and Nwagbo [7] reported $19.72 \%$ for single women in Abia, South-East, Nigeria with $21.6 \%$ and $11 \%$ among Abeokuta and Maiduguri married women respectively $[8,38]$.

Data have shown that HIV could escalate infection with $T$. vaginalis $[61,75,76]$. Isiaka-Lawal et al. [64] observed that the prevalence of trichomoniasis was higher in HIV infected women than their uninfected counterparts in north-central Nigeria, while in Lagos, a prevalence of $35.8 \%$ were noted in HIV positives [77].

Available data had revealed an increased risk of $T$. vaginalis infection in persons with poor personal hygiene and low socioeconomic status [78]. Levels of education have been linked to prevalence rate. For instance, non-formal educated women had an infection rate of $22.3 \%$ while tertiary educated women had only $1.0 \%$ [8]. Also, Usanga et al. [24] reported that women with primary school education had $6.4 \%$ prevalence rate. In addition, poverty, unemployment, violence against women and children [17,24], and young age could raise the risk associated with acquiring $T$. vaginalis infection $[63,79]$.

\section{Diagnosis}

Diagnostic methods available for trichomoniasis are wet mount preparation, staining methods, culture in laboratory medium, and molecular methods. Historically, detection of the parasite is made possible by examination of urine and High Vaginal Swab (HVS) in a drop of saline or trichomonas diluents for the characteristic wobbling and rotating motion. Amadi and Nwagbo [7] reported that either urine sample or vaginal swab is insufficient for proper diagnosis of $T$. vaginalis infection and have suggested that for better results both urine and vaginal swab should be used. Diagnosis of trichomoniasis has relied mostly on wet mount demonstration and staining of the parasite in the laboratory with success rate of between 20 and $80 \%$ [80]. A combination of cultural method with microscopic wet mount demonstration is now the acceptable procedure for effective diagnosis [81].

New molecular diagnostic tests with improved sensitivity have been developed in response to the increasing recognition by stakeholders of the importance of this wide-spread STI. Thus the detection of $T$. vaginalis, including rapid antigen detection and nucleic acid amplification tests, has significantly improved the quality of diagnostics for trichomoniasis, particularly in women [82]. In America, Guillermo et al. [83] reported 97\% sensitivity for molecular amplification diagnostic methods, as against 70 and $36 \%$ sensitivities for culture and wet preparations respectively. Also, studies of genetic typing of the parasites have been reported to be more sensitive than other methods $[84,85]$. However, in Nigeria there is no report of the application molecular diagnosis tools on $T$. vaginalis infection, which may influence the prevalence data as presently reported from less reliable tests.

\section{DALYs and Infection Burden}

Evaluation of the disease burden is essential in determining the cost-effectiveness of control so as to ensure that control 
programmes are focused appropriately. Disability Adjusted Life Year (DALYs) is the trending metric measurement to assess disease burden [86]. DALYs include years of life lost due to mortality (YLLs) and years lived with disability (YLDs). Most $T$. vaginalis survey is mainly on women, but reports of infection burden measured in DALYs are unavailable. Here we have estimated value of YLD based on available prevalence data and morbidity of the infection [87]. YLD due to TV in this review was estimated using the formula below [88].

$Y L D=P \times D W$

Where, $P=$ number of prevalent cases, $D W=$ Disability Weight.

Here, prevalence was used rather than incidence [88], because in Nigeria, surveys are widely reported in prevalence (Table 2). DW (0.027) of infection which is represented on a scale of $0-1$ $(0=$ perfect health; $1=$ death), was adopted [89]. YLDs due to $\mathrm{TV}$, according to the geopolitical zones are shown in Table 2. This review shows that the YLD from $T$. vaginalis prevalence data in Nigeria ranged from 21 to 63 with the highest and least disease burden recorded in South-South and North-West respectively.

Table 2. T. vaginalis mean prevalence and estimated YLD according to geopolitical zones (1984-2017).

\begin{tabular}{lll}
\hline Region & Mean \pm SD (\%) & YLD /10 000 \\
\hline South-East & $16.12 \pm 9.9$ & 44 \\
\hline South-South & $23.3 \pm 16.3$ & 63 \\
\hline South-West & $17.3 \pm 20.2$ & 47 \\
\hline North-West & $7.6 \pm 7.3$ & 21 \\
\hline North-East & $11.4 \pm 9.0$ & 31 \\
\hline North-Central & $12.5 \pm 12.4$ & 34 \\
\hline
\end{tabular}

\section{Control}

Control and elimination may depend largely on extensive proper sex education, especially for the adolescent and youths $[7,8]$. Also suggested are adequate treatment of both spouses, implementation of effective screening programmes and treatment at no cost [8]. For improved health, adequate personal hygiene, avoidance of promiscuity, improved education of women on safe sex and the need to know partners' STI status are advocated [14,77]. It is recommended that routine STIs screening in sexually active patients especially among the young and singles should be incorporated into hospital care [41]. This is needed to prevent transmission of the parasite, because some infected women and most infected men show no signs of the disease like liquid discharge from the vagina or penis, irritation while urinating and genital itching. So this YLD information is vital to focusing efforts on getting women tested and treated Based on the results from this study, trichomoniasis control in Nigeria should especially be of high priority in the South-South.

\section{Conclusion}

Data available in this review have clearly outlined the prevalence of trichomoniasis in Nigeria, with the South-South having the highest disease burden. The dearth of information and very poor awareness of this STDs among the populace may have impacted on the burden of infection. Thus, increased awareness on the parasite and the disease at all levels is highly recommended. Also, ensuring that health workers include $T$. vaginalis as part of a routine procedure in the course of screening for STDs is thus advocated. Furthermore, providing better sensitive methods for diagnosis is the way to go as this would ensure near-accurate information on the prevalence of the disease in any given area in Nigeria.

\section{References}

1. World Health Organization Report. Fighting disease, Fostering development. World Health Organization, Geneva, Switzerland 1996; 133.

2. WHO. Prevention and control of sexually transmitted infections: Draft global strategy. Ref Type: Generic 2006.

3. World Health Organization. Global prevalence and incidence of selected curable sexually transmitted infections: overview and estimates. Geneva, Switzerland 2001.

4. Okwute LO. A review of sexually transmitted diseases (STDs) of parasitic origin: The case of giardiasis. Afr J Biotechnol 2008; 7: 4979-4981.

5. Levine GI. Sexually transmitted parasitic diseases. Primary Care 1991; 18: 101-128.

6. Okafor CF, Omudu AE. Parasitic diseases and sexual disability: A critical review of some parasitic diseases with serious repercussions. Anim Res Int 2005; 2: 255-260.

7. Amadi ANC, Nwagbo AK. Trichomonas vaginalis infection among women in Ikwuano, Abia State, Nigeria. J Appl Sci Env Manag 2013; 17: 389-393.

8. Hamafyelto HS, Ikeh IE. Prevalence of Trichomonas vaginalis infection among female internally displaced persons in Maiduguri, Nigeria. Int J Trop Dis Health 2017; 27: 1-7.

9. Jatau ED, Olonitola OS, Olayinka AT. Prevalence of Trichomonas infection among women attending antenatal clinics in Zaria, Nigeria. Ann Afr Med 2006; 5: 178-181.

10. Opara K, Udoidiung N, Atting I, Bassey E, Okon O, Nwabueze A. Risk factors for vaginal trichomoniasis among women in Uyo, Nigeria. Intern J Health 2008; 9: $1-5$.

11. Nweze EI, Mouneke GN. Trichomonas vaginalis in HIV/ AIDS subjects in Nigeria. Asian Pac J Trop Dis 2011; 4: 282-286.

12. Onyemelukwe NF, Nwokocha ARC. Trichomonas vaginalis infection in male adolescents in parts of South Eastern Nigeria. IOSR J Dent Med Sci 2013; 12: 52-53.

13. Uneke CJ, Alo MN, Ogbu O, Ugwuoru DC. Trichomonas vaginalis infection in human immunodeficiency virus- 
seropositive Nigerian women: The public health significance. Onl J Health Allied Sci 2007; 6: 1-7.

14. Iwueze MO, Ezeanyanwu LN, Okafor FC, Nwaorgu OC, Ukibe SC. Prevalence of Trichomonas vaginalis infection among women attending hospitals/health centres in Onitsha community, Onitsha North Local Government area of Anambra State. Bioscientist 2014; 2: 54-64.

15. Kanu AM, Ihekwumere I, Kalu EJ. Frequency distribution of Trichomoniasis in pregnant women in Aba, South East, Nigeria. Univ J Microbiol Res 2015; 3: 53-55.

16. Onyido AE, Umeanaeto PU, Irikannu KC, Ekwunife CA, Ezeanya LC, Nwangwu UC, Ugha CN, Obiechina IO. Prevalence of Trichomonas vaginalis among the rural women of Ekwulumili community Anambra state, Southeastern Nigeria. Nat Sci 2014; 12: 129-134.

17. Ulogu IO, Obiajuru IO, Ekejindu IM. Prevalence of trichomoniasis amongst women in Nnewi, Anambra state, Nigeria. Niger J Parasitol 2007; 28: 6-10.

18. Orji NM. Reproductive tract infections among females in Ihiala Local Government area, Anambra State, Nigeria. Int J Sci Eng Appl Sci 2015; 1: 22-28.

19. Okonkwo EC, Iroha IR, Onwa NC, Nworie O, Oji Egwu A. Trichomonas vaginalis associated with adverse pregnancy outcomes: implications for maternal health care delivery system in South Eastern Nigeria. British J Med Med Res 2012; 2: 568-574.

20. Sunday-Adeoye IM, Adeoye JOK, Odidika UJU, Okonta P. The prevalence of Trichomonas vaginalis and Candida albicans infection in the lower genital tracts of antenatal patients in Abakaliki, Southeastern Nigeria. Nepal J Obstetr Gynaecol 2009; 4: 11-14.

21. Okonkwo EC, Amadi ES, Idioha JC, Nworie O, Nwuzo AC, Onwe JC. Prevalence of Trichomonas vaginalis among pregnant women in Abakaliki, Ebonyi State. Int J Curr Res 2010; 11: 11-15.

22. Acholonu ADW. Trichomoniasis: A little recognized sexually transmitted disease but with grave consequences. Publ Lect Nigeria Acad Sci Lagos 1998.

23. Ochei KC, Obeagu EI, Ugwu GU, George CN. Prevalence of Trichomonas vaginalis among pregnant women attending hospital in Irrua Specialist Teaching Hospital in Edo State, Nigeria. IOSR J Dent Med Sci 2014; 13: 79-82.

24. Usanga V, Abia-Bassey L, Inyang-Etoh P, Udoh S, Ani F, Archibong E. Trichomonas vaginalis infection among pregnant women in Calabar, Cross River State, Nigeria. Intern J Gynecol Obstetr 2009; 14: 1-7.

25. Pondie K, Jeremiah I, Lawani E, Nsikak E. The prevalence of symptomatic vulvo-vaginal candidiasis and Trichomonas vaginalis infection and associated risk factors among women in the Niger Delta Region of Nigeria. Int STD Res Rev 2017; 5: 1-10.

26. Akinbo FO, Mokobia $\mathrm{CN}$, Ande AB. Prevalence of trichomoniasis among pregnant women in Benin City. Sahel Med J 2017; 20: 67-71.
27. Olorode OA, Mark OO, Ezenobi NO. Urinogenital trichomoniasis in women in relation to candidiasis and gonorrhea in University of Port-Harcourt Teaching Hospital. Afr J Microbiol Res 2014; 8: 2482-2485.

28. Abah AE. Trichomonas vaginalis infection in a typical urban and a sub-urban area of Rivers state, Nigeria. Asian J Med Health 2017; 6: 1-6.

29. Akinbo FO, Oronsaye IS. Trichomonas vaginalis infection among adolescent girls in some secondary schools in Benin City, Edo State, Nigeria. Afr J Clin Exp Microbiol 2017; 18: 223-229.

30. Akpan UI. The prevalence of Trichomonas vaginalis in Uyo Local Government area of Akwa Ibom State, Nigeria. Int J Mod Biol Med 2013; 4: 134-139.

31. Ekanem EI, Ekott M, Udo AE, Efiok EE, Inyang-Out A. Prevalence of sexually transmitted diseases in pregnant women in Ikot Epene, a rural community in Akwa Ibom State, Nigeria. Op J Obstetr Gynaecol 2012; 2: 49-55.

32. Okoko FJ. Prevalence of Trichomoniasis among women at Effurun metropolis, Delta State, Nigeria. Continent JBiol Sci 2011; 4: 45-48.

33. Wokem GN, Ndukwu CB. Re-evaluation of vulvovaginal trichomoniasis among women in Niger Delta region, Nigeria. Glob J Pure Appl Sci 2015; 21: 13-19.

34. Oyewole IO, Anyasor GN, Michael-Chikezie EC. Prevalence of STI pathogens in HIV-infected and Noninfected women: implications for acquisition and transmission of HIV in Nigeria. Asian J Med Sci 2010; 2: 163-166.

35. Olaniran O, Osevwe AJ, Balogun IA, Hassan-Olajokun RE, Oyetoke OO. The prevalence of Trichomonas vaginalis in Wesley Guide Hospital, Ilesha, Nigeria. Int J Microbiol Res Rev 2017; 6: 345-350.

36. Donbraye E, Donbraye-Emmanuel OOB, Okonko IO, Okedeji IO, Alli JA, Nwanze JC. Detection and prevalence of Trichomonas vaginalis among pregnant women in Ibadan, South-Western Nigeria. W Appl Sci J 2010; 11: 1512-1517.

37. Olowe OA, Makanjuola OB, Olowe R, Adekanle DA. Prevalence of vulvovaginal candidiasis, trichomoniasis and bacterial vaginosis among pregnant women receiving antenatal care in South Western Nigeria. Eur J Microbiol Immunol 2014; 4: 193-197.

38. Etuketu MI, Mogaji OH, Alabi MO, Adeniran AA, Oluwole SA, Ekpo FU. Prevalence and risk factors of Trichomonas vaginalis infection among pregnant women receiving antenatal care in Abeokuta, Nigeria. Afr J Infect Dis 2015; 9: 51-56.

39. Ojurongbe O, Taiwo BO, Dina BO, Sina-Agbaje OR, Bolaji OS, Adeyeba AO. Prevalence of Trichomonas vaginalis infection among pregnant women in Abeokuta, Nigeria. Sierra Leone J Biomed Res 2010; 2: 82-86.

40. Oyetunde TO, Olamide F, Ifeoluwa TO. Trichomonas vaginalis infection in Nigerian pregnant women and risk factors associated with sexually transmitted infections Int J STD AIDS 2015; 27: 1187-1193. 
41. Okonko IO, Okerentugba PO, Adejuwon AO, Onoh CC. Prevalence of sexually transmitted infections (STIs) among attendees of Lead City University Medical Centre in Ibadan, South-Western, Nigeria. Arc Appl Sci Res 2012; 4: 980-987.

42. Bolaji OS, Adejare FO, Adeyeba OA, Ojurongbe O. Comparison of methods of diagnosis of Trichomoniasis in pregnancy among ante-natal patients in some parts of Oyo state. Int J Pharm Med Biol Sci 2013; 2: 5-12.

43. Adeoye GO, Akande AH. Epidemiology of Trichomonas vaginalis among women in Lagos metropolis, Nigeria. Pak J Biol Sci 2007; 10: 2198-2201.

44. Ebhodaghe BI, Ako-Nai KA, Aderoba AK, Anderson WA, Kassim OO. Co-infections of human immunodeficiency virus and sexually transmitted infections among hiv seropositive pregnant women at healthcare centres in Akure, Southwestern Nigeria. Int Arc Med 2016; 9: 1-8.

45. Olorunfemi OB, Ijabadeniyi AO. Prevalence of Trichomonas vaginalis in urogenital tract infection in Akure South Local Government area, Ondo state. Ife J Sci 2005; 7: 159-161.

46. Bakare RA. Prevalence of Trichomonas vaginalis among the sexual partners of women with Trichomoniasis in Ibadan, Nigeria. Afr J Clin Exp Microbiol 2003; 4: 107-115.

47. Senchi JH, Samson ES, Olumuyiwa A, Eleojo IG, Oluchi OG, Olusola OA. The prevalence of Trichomonas vaginalis infection and associated risk factors among undergraduate female students of Babcock University, Ilishan-Remo, Ogun state, Nigeria. Int STD Res Rev 2017; 6: 1-13.

48. Anorlu RI, Fagbenro-Beyioku AF, Fagorala T, Abudu OO, Galadanci HS. Prevalence of Trichomonas vaginalis in patients with vaginal discharge in Lagos, Nigeria. Niger Postgrad Med J 2001; 8: 183-186.

49. Avidime S, Sulayman HU, Adesiyun AG. Prevalence of Trichomonas vaginalis and HIV co-infection among asymptomatic pregnant women in Zaria, Northern Nigeria. J Health Res Rev 2017; 1: 49-53.

50. Abubakar A, Arzika S, Aliyu F, Umar H, Abubakar HM. Detection and prevalence of Trichomonas vaginalis among women in Birnin Kebbi, North West, Nigeria. Int J Res Find Eng Sci Technol 2013; 1: 23-27.

51. Ahmad MM, Yahaya G, Shuaibu I, Abdullahi II. Urinary tract infections among female patients attending BarninKudu General Hospital, Jigawa, Nigeria. Dutse J Pure Appl Sci 2016; 2: 166-170.

52. Nwadioha S, Egesie JO, Emejuo H, Iheanacho E. Prevalence of pathogens of abnormal vaginal discharges in a Nigerian Tertiary Hospital. Asian Pac JTrop Med 2010; 3: 483-485.

53. Akafyi DE, Oko JO, Umar M, Obafemi A, Michael R. Prevalence of bacterial, Trichomonas and Candidal Vaginosis among females in Angwan-Fulani, Palladan in Zaria, Nigeria. J Appl Life Sci Int 2016; 5: 1-6.
54. Isaac N, Onwuhafua PI, Oguntayo AO, Opaluwa AS. Routine screening for Trichomonas vaginalis among human immunodeficiency virus-seropositive antenatal clients in Zaria: A necessity or option? Trop J Obstetr Gynaecol 2016; 33: 322-326.

55. Mairiga AG, Balla HJ, Ahmad MI. Prevalence of Trichomonas vaginalis infections among antenatal clients in Maiduguri, Nigeria. Int J Biol Med Res 2011; 2: 998-1002.

56. Abdulazeez A, Alo E, Naphthali R. Urino-genital trichomoniasis and human immune-deficiency virus concurrent infection in Adamawa state, Nigeria. Intern $\mathrm{J}$ Paras Dis 2007; 3: 1-6.

57. Anejo-Okopi AJ, Simji G, Okon EB, Ejeliogu UE, Okojokwu OJ, Okechalu J, Mafuyai S, Efekamaraye E, Isa SE. Prevalence and factors associated with Trichomonas vaginalis among HIV-1 positive women attending tertiary hospital in Jos, Nigeria. Saudi J Pathol Microbiol 2017; 2: 269-275.

58. Abioye JOK, Ihuma JO, Abdullahi DK, Kamoh N, Awari YS, Gemma K, Babatunde SK. Trichomonas vaginalis among pregnant women attending New Nyanya General Hospital, Nasarawa State, Nigeria. Int J Sci Nat 2014; 5: 437-439.

59. Yako AB, Maria FI, Hassan SC, Chassed G, Katuka G. Trichomonas vaginalis: the most prevalent sexually transmitted infection (STI) among female patients, a cause for medical care at Nagari Hospital (NH), Keffi, Nasarawa State, Nigeria. W Sci Res J 2014; 2: 67-70.

60. Bolaji OS, Ajadi TS, Bello SA, Ojurongbe O, Adeyeba OA. Prevalence of Trichomonas vaginalis among pregnant women from selected hospitals in Ilorin metropolis. J Pharm Sci Innov 2015; 4: 108-111.

61. Okojokwu OJ, Akpakpan EE, Kolawole OT, Ndubuisi JC, Okopi JA. Epidemiology of Trichomonas vaginalis infection among women in Jos metropolis, Nigeria. Biomed Nurs 2015; 1: 7-11.

62. Olarenwaju CA. Incidence of trichomoniasis among primary school pupils in Gwagwalada, FCT, Nigeria. J Life Sci Technol 2016; 4: 40-43.

63. Aboyeji AP, Nwabuisi C. Prevalence of sexually transmitted diseases among pregnant women in Ilorin, Nigeria. J Obstetr Gynaecol 2003; 23: 637-639.

64. Isiaka-Lawal SA, Nwabuisi C, Fakeye O, Saidu R, Adesina KT, Ijaiya MA, Jimoh AA, Omokanye LO. Pattern of sexually transmitted infections in human immunodeficiency virus positive women attending antenatal clinics in North-Central Nigeria. Sahel Med J 2014; 17: 145-150.

65. Okoh ME, Igbaaka IM. Prevalence of Trichomonas vaginalis among females visiting some selected hospitals in Makurdi, Benue State Nigeria. Int $\mathrm{J}$ Microbiol Biotechnol 2017; 2: 43-47.

66. Gberikon GM, Aguoru CU, Yandev D. Prevalence of Schistosoma haematobium and Trichomonas vaginalis in relation to age distribution and marital status among 
patients attending four selected hospitals in Gboko, Benue state of Nigeria. Int J Pure Appl Sci Technol 2015; 29: 26-30.

67. Hussaini Y, Adegda JA, Abdulkadir A, Suleiman A, Murtala SE, Jibrin Y, Yakubu Y. Prevalence of Trichomonas vaginalis among female patients attending the General Hospital Nasarawa, Nasarawa State. Cell Biol 2017; 5: 8-11.

68. Alaku IA, Abdulllahi AG, Attah DD. Prevalence of human Trichomonas vaginalisinfections in some parts of Nasarawa State, Nigeria. J Med Biol Sci 2014; 4: 8-16.

69. Raimi MO, Ochayi EO. Assessment of the rate of sexually transmitted diseases in Kubwa F.C.T, Abuja, Nigeria. Sci J Publ Health 2017; 5: 365-376.

70. Adogo LY, Oyewole EA, Anyanwu NCJ, Omebije PE. Prevalence and correlates of Gardnerella vaginalis and Trichomonas vaginalis among female students in Bingham University. Int J Trop Dis Health 2016; 20: 1-8.

71. Nwadioha SI, Bako IA, Onwuezobe I, Egah DZ. Vaginal trichomonas among HIV patients attending primary health care centres, Jos, Nigeria. Asian Pac J Trop Dis 2012; 2: 337-341.

72. Njoku AJ, Obiajuru IOC, Njoku CJ, Nwokoro EA, Uwaezuoke IC, Anosike IC. Prevalence of Trichomonas vaginalis infection among students of tertiary institutions in Imo state, Nigeria. Niger J Parasitol 2000; 21: 83-94.

73. Obiajuru IOC. Prevalence of Trichomonas vaginalis in Owerri, Imo state. M.Sc. Thesis, Imo State University, Owerri 2000.

74. Obiajuru IOC, Ogbulie JN. Prevalence of sexually transmitted diseases in three zones of Imo state, Nigeria. Niger J Microbiol 2007; 21: 1491-1498.

75. Sorvillo F, Kerndt P. Trichomonas vaginalis and amplification of HIV-1 transmission. Lancet 1998; 351: 213-214.

76. Laga M, Manoka A, Kivuvu M. Non-ulcerative sexually transmitted diseases as risk factors for HIV-1 transmission in women: results from a cohort study. AIDS 1993; 7 : 95-102.

77. Oyetunde TS, Chelsea NE. Frequency of Human Immunodeficiency Virus (HIV) in Trichomonas vaginalis infected women in Badagry, Lagos, Nigeria. J Reprod Infertil 2016; 17: 61-63.

78. Thomas CQ, King KH. Trichomoniasis. Tropical and geographical medicine. McGraw Hill Book Company, New York 1985; 340.

79. Obiajuru OC, Noku AJ, Ogbulie JN. Studies on the prevalence of sexually transmitted diseases amongst teenage hawkers in Lmo state Nigeria. Int J Env Health Human Develop 2004; 4: 104-119.
80. Fouts AC, Kraus SJ. Trichomoniasis vaginalis: revaluation of its clinical presentation and laboratory diagnosis. J Infect Dis 1980; 141: 137-143.

81. Arora DR, Arora B. Medical Parasitology (2nd Edn.). CBS. Publisher, New Delhi India 2005; 41-43.

82. Hobbs MM, Sena AC. Modern diagnosis of Trichomonas vaginalis infection. Sex Transmit Infect 2013; 89: 434-438.

83. Guillermo M, Thomas CQ, Anne R, Kelly TM, Charlotte AG. Diagnosis of Trichomonas vaginalis infection by PCR using vaginal swab samples. J Clin Microbiol 1998; 36: 3205-3210.

84. van Der Schee C, van Belkum A, Zwijgers L, van Der Brugge E, Oneill EL, Luijendijk A, van Rijsoort-Vos T, van Der Meijden WI, Verbrugh H, Sluiters HJ. Improved diagnosis of Trichomonas vaginalis infection by PCR using vaginal swabs and urine specimens compared to diagnosis by wet mount microscopy, culture, and fluorescent staining. J Clin Microbiol 1999; 37: 4127-4130.

85. Vanacova S, Tachezy J, Kulda J, Flegr J. Characterization of trichomonad species and strains by PCR fingerprinting. J Eukaryot Microbiol 1997; 44: 545-552.

86. Brooker S. Estimating the global distribution and disease burden of intestinal nematode infections: adding up the numbers-a review. Int J Parasitol 2010; 40: 1137-1144.

87. Bartsch SM, Hotez PJ, Asti L, Zapf KM, Bottazzi ME, Diemert DJ. The global economic and health burden of human hookworm infection. PLoS Negl Trop Dis 2016; 10: 0004922.

88. Murray CJL, Ezzati M, Flaxman AD, Lim S, Lozano R, Michaud C. Years lived with disability (YLDs) for 1160 sequelae of 289 diseases and injuries 1990-2010: a systematic analysis for the Global Burden of Disease Study 2010. Lancet 2012; 380: 2197-223.

89. Salomon JA, Haagsma JA, Davis A, de Noordhout CM, Polinder S, Havelaar AH. Disability weights for the Global Burden of Disease 2013 study. Lancet Glob Health 2015; 3: 712-723.

\section{*Correspondence to}

Omorodion Oriri Asemota

Industrial Safety and Environmental Technology Department

Petroleum Training Institute

Nigeria 